\title{
Comparative Study of Student Leadership Attitudes and Discipline Attitudes
}

\author{
Dwi Asih Kumala Handayani ${ }^{1, *}$, Sri Sayekti ${ }^{2}$, Sri Redjeki $^{1}$, Elfi Rimayati ${ }^{1}$, Lili Marliyah ${ }^{2}$, \\ Maria Agustiningrum ${ }^{3}$
}

\begin{abstract}
${ }^{1}$ Department of Guidance and Counseling, Faculty of Teacher Training and Education, Ivet University, Semarang, Indonesia ${ }^{2}$ Department of Economic Education, Faculty of Teacher Training and Educational Sciences, Ivet University, Semarang, Indonesia ${ }^{3}$ Department of Early Childhood Teacher Education, Faculty of Teacher Training and Education, Ivet University, Semarang, Indonesia
\end{abstract}

Received September 28, 2020; Revised November 27, 2020; Accepted January 20, 2021

\section{Cite This Paper in the following Citation Styles}

(a): [1] Dwi Asih Kumala Handayani, Sri Sayekti, Sri Redjeki, Elfi Rimayati, Lili Marliyah, Maria Agustiningrum, "Comparative Study of Student Leadership Attitudes and Discipline Attitudes," Universal Journal of Educational Research, Vol. 9, No. 1, pp. 53 - 59, 2021. DOI: 10.13189/ujer.2021.090106.

(b): Dwi Asih Kumala Handayani, Sri Sayekti, Sri Redjeki, Elfi Rimayati, Lili Marliyah, Maria Agustiningrum (2021). Comparative Study of Student Leadership Attitudes and Discipline Attitudes. Universal Journal of Educational Research, 9(1), 53 - 59. DOI: 10.13189/ujer.2021.090106.

Copyright $\mathrm{C} 2021$ by authors, all rights reserved. Authors agree that this article remains permanently open access under the terms of the Creative Commons Attribution License 4.0 International License

\begin{abstract}
Discipline is essential and must-have for every student. Discipline helps students form attitudes and behaviors and will lead students successfully in learning and at work later. Leadership is a behavior or way chosen and used in influencing the thoughts, feelings, attitudes, and behaviors of members of the organization. Objective: to know how to develop leadership attitudes and discipline attitudes in the implementation of school organizations. Know the role of school organizations in shaping leadership attitudes and discipline attitudes. Methods: interactive discussions, training methods or games/ simulations, and tests. Pre-test and post-test results show that students have a high leadership attitude, as well as having a reasonably good discipline attitude. Pre-test and post-test were conducted to prove that the training provided can improve students' attitude of leadership and discipline attitude. The results of the paired t-test proved that leadership attitudes do not directly affect students' discipline attitudes. The increase in variable value is the result of training. The critical thing that researchers get from this study is that leadership attitudes are inversely proportional to disciplinary attitudes. Conclusion: School organizations in shaping leadership attitudes and discipline attitudes have a very high role. The development of leadership attitudes and disciplinary attitudes to school organization organizers is carried out through training, as well as other activities that support leadership attitudes and discipline attitudes.
\end{abstract}

Keywords Leadership Attitude, Discipline Attitude, School Organization

\section{Introduction}

Discipline helps students form attitudes and behaviors and leads them to succeed in learning and at work later. Disciplinary functions (Tu'u, 2004), (Meitha \& Sasmito, 2016) [1,2] among others; organizing co-living, discipline is useful to realize that a person needs to be respected by obeying the applicable rules, so as not to harm others and establish good relationships with others, as well as build a developing personality. A person's personality is usually influenced by environmental factors (Bekti Agustiningrum, 2018), (Whiteneck \& Dijkers, 2009) [3,4]. The discipline applied in each environment has an impact on the growth of a good personality (Lickona, 2013) (Yudhawati, 2018) [5,6]. Therefore with a discipline attitude, the person will get used to following, obeying the rules and habits that apply will eventually build a good personality. Practicing good personality, attitude, behavior, and lifestyle, and discipline is not formed suddenly in a short time. However, it is formed through a process that takes a long time. One of the processes of personality formation is through training (Deni, 2018) [7]. 
Discipline can occur due to the encouragement of self-awareness. With having self-awareness, the attitude of discipline will be better (Handayani, 2018) [8]. Conversely, discipline can also occur due to coercion and pressure from outside (Mulyasa, 2013) [9]. The school needs and is obliged to organize student development by providing provisions and abilities to students to develop student potential through extracurricular organizations in schools in addition to learning in the classroom, namely through student activities, namely through OSIS, PMR, Pramuka, Paskibra, and so on; it is hoped that through this organization activities can bring changes to students as an effort to develop the personality and character of students that is to have a right and correct leadership attitude (Muslich, 2008), (Retmono, 2016) [10,11]. In organizing, students will learn democratically directly even though there is still limited coverage, but the size of students who are still teenagers is quite right. Supervisors or chairpersons of student organizations such as OSIS, PMR, Pramuka, and Paskibra, have usually been appointed by the school, namely through democratic elections. The deputy headmaster assists the headmaster in the student sector as the main person in charge of this activity. In carrying out this activity, sometimes in the field, there are problems, such as the occurrence of disciplinary violations committed by organizers who do not follow coaching or routine activities. These problems occur frequently and are part of coaching duties.

Another problem is that there are students who participate in school organization activities only to join or simply want to "get on the fame" to be better known by their juniors and by other students or teachers (Rivai et al., 2014) [12]. Besides, some students are forced to participate in school organization activities because they are appointed by a teacher or friend or asked by their parents to be active in school organization activities (Wartono, 2017) [13]. Sometimes when there is a meeting of school organization activities, there are still members or administrators who are not present. However, not a few students consciously and disciplined participated in organizational activities without being forced (Ahmad \& Salim, 2011) [14]. These students participated in activities based on their interest in joining the organization to develop their talents and hoped to gain more knowledge and experience and more friends (Mandey \& Sahangggamu, 2014) [15]. Students who participate in school organization activities should not only be involved in activities because organizing requires seriousness and activeness from students so that students can actually learn democratic in organizing (Susanty \& Baskoro, 2013), (Moraes et al., 2019) [16,17]. With the involvement of students in school organization activities are expected to provide significant benefits that produce students who are characteristic and leadership spirit such as courageous to lead, dare to make decisions, dare to express opinions, be willing to accept criticism, have a chivalrous attitude, advice, open, honest, responsible, respect opinions, maintain and appreciate togetherness, trust, fairness, discipline, and so forth (Sari et al., 2012) (Syahrial, Asrial, Husni Sabil, 2020) [18,19]. In addition, the involvement of students in school organization activities is expected to minimize the occurrence of irregularities and harmful actions that are often carried out by teenagers or students, such as smoking, drinking alcohol, drugs, and even free association (Stevens, 2011), (Nasir \& Rosenthal, 2009) (Gunarsa; Gunarsa, 2016) [20-22].

\section{Materials and Methods}

A quantitative method with a comparison of research design compares the variable attitudes of leadership towards student discipline (Möller et al., 2020) [23]. Comparative studies are conducted through pre-tests and post-tests on the condition of leadership attitudes and discipline attitudes before and after training/simulation. Furthermore, the correlation test determines whether there is a relationship or influence between the pre-test and post-test results of each variable (Rismayadi \& Maemunah, 2016) [24]. Lastly, pre-test and post-test are done to determine whether there are differences in leadership attitudes and discipline attitudes before and after activities are carried out. The research objectives are active members of the school's student organization, including administrators and organization members.

Materials and tools used are pre-test and post-test guidelines, observation guidelines, interview guidelines, instrument testing tools, training, game materials, question and answer questions, and interactive discussion materials. Before pre-test and post-test are done, researchers conducted the instrument's validity and reliability test as well as data normality test.

The instruments used are two questionnaire instruments, which include questions related to leadership attitudes with 25 questions as well as a discipline with 25 questions. The instrument uses a Likert scale with four very high answer options score 4, high score 3, medium score 2, and less score 1 (Jaupllari \& Olta Zoto, 2013) [25]. Questions in instrument variable $x$ used to measure the quality of leadership attitudes, and questions in instrument variable y used to measure cauldrons of discipline. The instrument has been tested for validity and reliability and is considered eligible for reliability (Solanki et al., 2020) [26].

The data used is the result of the SPSS 24 program to find descriptive data and inferential statistics, median, maximum, deviation. Statistics results are obtained from the results of calculations and procedures using probability and information about populations and research samples. Besides, there are prerequisite tests and hypothesis tests, as well as hypothetical test results using product moment techniques $(\mathrm{R}, 2011)$ [27]. 


\section{Results}

The results of the normality test of leadership attitude data and the normality test of discipline attitudes obtained the following data:

Table 1. Results of the Leadership attitude normality test

\begin{tabular}{|c|c|c|c|c|c|c|}
\hline \multicolumn{7}{|c|}{ Descriptive Statistics } \\
\hline & $\mathrm{N}$ & Mean & \multicolumn{2}{|c|}{ Skewness } & \multicolumn{2}{c|}{ Kurtosis } \\
\cline { 2 - 7 } & Statistic & Statistic & Statistic & $\begin{array}{c}\text { Std. } \\
\text { Error }\end{array}$ & Statistic & $\begin{array}{c}\text { Std. } \\
\text { Error }\end{array}$ \\
\hline $\begin{array}{c}\text { Leadership } \\
\text { Attitude }\end{array}$ & 30 & 89.57 & -.675 & .427 & -.637 & .833 \\
\hline Valid N (listwise) & 30 & & & & & \\
\hline
\end{tabular}

Skewness-Kurtosis decision basis: leadership attitude If the skewness-kurtosis ratio values between $(-2)$ to $(+2)$ then the data is distributed normally. Skewness Ratio = $-.675 / 0.427=-1.58129$, Kurtosis Ratio $=-0.637 / 0.833$ $=-0.76509$

Conclusion: Normal distributed Leadership Attitude

Table 2. Basic Decisions Skewness Kurtosis Discipline Attitude

\begin{tabular}{|c|c|c|c|c|c|c|}
\hline \multicolumn{7}{|c|}{ Descriptive Statistics } \\
\hline & $\mathrm{N}$ & Mean & \multicolumn{2}{|c|}{ Skewness } & \multicolumn{2}{c|}{ Kurtosis } \\
\cline { 2 - 7 } & Statistic & Statistic & Statistic & $\begin{array}{c}\text { Std. } \\
\text { Error }\end{array}$ & Statistic & $\begin{array}{c}\text { Std. } \\
\text { Error }\end{array}$ \\
\hline $\begin{array}{c}\text { Discipline } \\
\text { Attitude }\end{array}$ & 30 & 77.77 & .451 & .427 & -.558 & .833 \\
\hline $\begin{array}{c}\text { Valid N } \\
\text { (listwise) }\end{array}$ & 30 & & & & & \\
\hline
\end{tabular}

Basis of Skewness-Kurtosis decision: Discipline Attitude If the skewness-kurtosis ratio value is between $(-2)$ to $(+2)$ then the data is distributed normally. Slope ratio $=0.451 / 0.427=1.056879$, Kurtosis Ratio $=-0.558 /$ $0.833=-0.66971$. The results explain that the variables of discipline data are distributed normally.

\section{T-Test Results Paired Leadership Attitudes:}

Table 3. T-Test Results Paired Leadership Attitudes

\begin{tabular}{|c|c|c|c|c|}
\hline \multicolumn{5}{|c|}{ Paired Samples Statistics } \\
\hline & Mean & N & Std. Deviation & Std. Error Mean \\
\hline Pre test & 89.5667 & 30 & 7.55980 & 1.38022 \\
\hline Post test & 93.5333 & 30 & 6.54814 & 1.19552 \\
\hline
\end{tabular}

Mean of pretest $=89.5667$, mean of posttest $=93.5333$

Table 4. Correlation results or relationship between pre-test values and post-test Leadership Attitudes

\begin{tabular}{|c|c|c|c|c|}
\hline \multicolumn{5}{|c|}{ Paired Samples Correlations } \\
\hline \multicolumn{2}{|c|}{} & N & Correlation & Sig. \\
\hline Pair 1 & Pre test \& Post test & 30 & -.200 & .289 \\
\hline
\end{tabular}

Correlation result or relationship between pre-test value and post-test leadership attitude: Is there a relationship between pre-test and post-test score through Pearson product-moment correlation test. A known significance value of 0.289 means that the value is more significant than $0.05(0.289>0.05)$, so it can be concluded that there is no relationship or no significant influence between pre-test and post-test on leadership attitude.

Paired Samples T-Test to know whether or not there is a difference between pre-test results and post-test leadership attitude.

Basic decision making:

1. If the value is sig. (2-tailed) $<0.05$, then there is a significant difference between the pre-test and post-test scores

2. If the value is sig. (2-tailed) $>0.05$, then there is no significant difference between the pre-test and post-test scores

It is known that sig. (2-tailed) of $0.057>0.05$, it is concluded that there is no significant difference between the pre-test and post-test scores.

Table 5. Paired Samples T-Test to find out whether or not there is a difference between pre-test results and post-test leadership attitudes

\begin{tabular}{|c|c|c|c|c|c|c|c|c|c|}
\hline \multicolumn{10}{|c|}{ Paired Samples Test } \\
\hline & & \multicolumn{5}{|c|}{ Paired Differences } & \multirow{3}{*}{$\mathrm{t}$} & \multirow{3}{*}{ df } & \multirow{3}{*}{ Sig. (2-tailed) } \\
\hline & & \multirow{2}{*}{ Mean } & \multirow{2}{*}{ Std. Deviation } & \multirow[t]{2}{*}{ Std. Error Mean } & \multicolumn{2}{|c|}{$\begin{array}{c}95 \% \text { Confidence Interval of the } \\
\text { Difference }\end{array}$} & & & \\
\hline & & & & & Lower & Upper & & & \\
\hline Pair 1 & $\begin{array}{l}\text { Pre test - Post } \\
\text { test }\end{array}$ & -3.96667 & 10.94653 & 1.99855 & -8.05417 & .12083 & -1.985 & 29 & .057 \\
\hline
\end{tabular}




\section{Paired T-Test Results for Discipline:}

Table 6. Paired T-Test Results for Discipline

\begin{tabular}{|c|c|c|c|c|c|}
\hline \multicolumn{6}{|c|}{ Paired Samples Statistics } \\
\hline \multicolumn{2}{|c|}{} & Mean & N & Std. Deviation & $\begin{array}{c}\text { Std. Error } \\
\text { Mean }\end{array}$ \\
\hline \multirow{2}{*}{ Pair 1 1 Pre test } & 77.7667 & 30 & 9.46749 & 1.72852 \\
\cline { 2 - 6 } & Post test & 83.4667 & 30 & 10.14289 & 1.85183 \\
\hline
\end{tabular}

Pretest mean $=77.7667$, posttest mean $=83.4667$

Table 7. Correlation results or relationship between pre-test values and post-test disciplinary attitudes

\begin{tabular}{|c|c|c|c|c|}
\hline \multicolumn{5}{|c|}{ Paired Samples Correlations } \\
\hline & & $\mathrm{N}$ & Correlation & Sig. \\
\hline $\begin{array}{c}\text { Pair } \\
1\end{array}$ & $\begin{array}{l}\text { Pre test \& } \\
\text { Post test }\end{array}$ & 30 & .015 & .938 \\
\hline
\end{tabular}

The result of the correlation or relationship between pre-test value and post-test disciplinary attitude revealed the relationship between pre-test value and post-test score through person product-moment correlation test. The known significance value of 0.938 , which means that the value is more significant than $0.05(0.938>0.05)$, so it can be concluded that there is no relationship or no significant influence between pre-test and post-test disciplinary attitude.

Paired Samples T-Test to determine whether or not there is a difference between the pre-test and post-test results.

Basic decision making:

1. If the value is sig. (2-tailed) $<0.05$, then there is a significant difference between the pre-test and post-test scores

2. If the value is sig. (2-tailed) $>0.05$, then there is no significant difference between the pre-test and post-test scores

It is known that sig. (2-tailed) of $0.031<0.05$, it is concluded that there is a significant difference between the pre-test and post-test scores.

Table 8. Paired Samples T-Test to find out whether or not there is a difference between pre-test results and post-test Attitude of Discipline

\begin{tabular}{|c|c|c|c|c|c|c|c|c|c|}
\hline \multicolumn{10}{|c|}{ Paired Samples Test } \\
\hline & & \multicolumn{5}{|c|}{ Paired Differences } & \multirow{3}{*}{$\mathrm{t}$} & \multirow{3}{*}{$\mathrm{df}$} & \multirow[t]{3}{*}{ Sig. (2-tailed) } \\
\hline & & \multirow{2}{*}{ Mean } & \multirow{2}{*}{ Std. Deviation } & \multirow[t]{2}{*}{ Std. Error Mean } & \multicolumn{2}{|c|}{\begin{tabular}{|c|}
$95 \%$ Confidence Interval of the \\
Difference
\end{tabular}} & & & \\
\hline & & & & & Lower & Upper & & & \\
\hline Pair 1 & $\begin{array}{l}\text { Pre test - Post } \\
\text { test }\end{array}$ & -5.70000 & 13.77191 & 2.51440 & -10.84252 & -.55748 & -2.267 & 29 & .031 \\
\hline
\end{tabular}

\section{Paired T-Test Results on Leadership Attitudes to Discipline:}

Table 9. Paired T-Test Results on Leadership Attitudes to Discipline

\begin{tabular}{|c|c|c|c|c|c|}
\hline \multicolumn{7}{|c|}{ Paired Samples Statistics } \\
\hline \multirow{2}{*}{ Pair 1 } & Mean & N & Std. Deviation & Std. Error Mean \\
\cline { 2 - 6 } & Leadership Attitude & 93.5333 & 30 & 6.54814 & 1.19552 \\
\hline & Discipline Attitude & 83.4667 & 30 & 10.14289 & 1.85183 \\
\hline
\end{tabular}

Average value (mean) of leadership attitude $=93.5333$, mean of discipline $=83.4667$

Table 10. Correlation results or relationship between leadership attitude score and discipline attitude score

\begin{tabular}{|l|c|c|c|c|}
\hline \multicolumn{7}{|c|}{ Paired Samples Correlations } & Correlation & Sig. \\
\hline Pair 1 & Leadership Attitude \& Discipline Attitude & 30 & -.026 & .893 \\
\hline
\end{tabular}

The result is a correlation or relationship between the leadership attitude score and the disciplinary attitude score. This study conducted to reveal is there a relationship between the values of leadership attitudes and the values of disciplinary attitudes through the Pearson product-moment correlation test.

A known significance value of 0.893 means that the value is more significant than $0.05(0.893>0.05)$, so it can be concluded that there is no relationship or no significant influence between leadership attitude and discipline attitude. 
Table 11. Paired Sample T-Test to see if there is a difference between Leadership Attitude score and Discipline Attitude score

\begin{tabular}{|c|c|c|c|c|c|c|c|c|c|}
\hline \multicolumn{10}{|c|}{ Paired Samples Test } \\
\hline & & \multicolumn{5}{|c|}{ Paired Differences } & \multirow{3}{*}{$\mathrm{t}$} & \multirow{3}{*}{$\mathrm{df}$} & \multirow{3}{*}{ Sig. (2-tailed) } \\
\hline & & \multirow{2}{*}{ Mean } & \multirow{2}{*}{ Std. Deviation } & \multirow{2}{*}{ Std. Error Mean } & \multicolumn{2}{|c|}{$\begin{array}{c}95 \% \text { Confidence Interval of } \\
\text { the Difference }\end{array}$} & & & \\
\hline & & & & & Lower & Upper & & & \\
\hline Pair 1 & $\begin{array}{c}\text { Leadership } \\
\text { Attitude \& } \\
\text { Discipline } \\
\text { Attitude }\end{array}$ & 10.06667 & 12.21343 & 2.22986 & 5.50610 & 14.62724 & 4.514 & 29 & .000 \\
\hline
\end{tabular}

Paired Samples T-Test used to know whether or not there is a difference between the results of the Leadership Attitude score and the Discipline Attitude score.

Basic decision making:

1. If the value is sig. (2-tailed) $<0.05$, then there is a significant difference between the values of leadership attitudes and disciplinary attitudes

2. If the value is sig. (2-tailed) $>0.05$, so there is no significant difference between the values of leadership attitudes and disciplinary attitudes

It is known that sig. (2-tailed) of $0.000<0.05$, it is concluded that there is a significant difference between the values of leadership attitudes and disciplinary attitudes.

\section{Discussion}

The t-test paired leadership attitude result obtained an average value (mean) pre-test $=89.5667$, while the mean value of post-test $=93.5333$.

Results of the correlation test know whether or not the relationship/influence between the pre-test and post-test leadership attitude value has reached a significant value of 0.289 and is greater than $0.05(0.289>0.05)$, meaning there is no significant relationship or influence between pre-test and post-test results on the value of leadership attitude.

Paired test results of the t-test samples to determine whether there is a difference between the pre-test and post-test results on the value of the leadership attitude achieved a significant value of 0.057 . This value is greater than $0.05(0.057>0.05)$. This means that there is no difference in value outcomes between the pre-test and post-test values of leadership attitudes.

Discussion of paired t-test results, correlation test, and paired test results of t-test leadership attitudes that the increase in pre-test average value (mean) 89.5667 and the post-test average value (mean) 93.5333 , is not due to the increase in test results. Because there is no relationship and no significant difference between pre-test and post-test evidence. The high value of leadership attitudes is likely derived from the influence of other variables, which still need to be followed up with other research.

The results of the t-test paired on the student's disciplinary attitude obtained the pre-test mean $=77.7667$, and the post-test mean $=83.4667$.

Correlation test results to prove whether or not there is a relationship/influence between the pre-test value and post-test value on the value of discipline attitude obtained a significant value of 0.938 , which means $0.938>0.05$, meaning there is no significant relationship or influence between pre-test and post-test value on discipline attitude.

Paired test results of t-test samples to find out whether there is a difference between the pre-test value and post-test value of discipline attitude obtained a significant value of 0.031 so that $0.031>0.05$, which means there is a significant difference in the value of pre-test and post-test on the value of discipline attitude.

Discussion of paired t-test results, correlation test, and paired test results of t-test discipline attitude that the increase in mean value at pre-test value (77.766) and post-test value (83.4667) is an increase in the value of training test results. This means that the training actions that have been done after the pre-test are carried out impact increasing test scores. There is an increase in the value of discipline attitudes in students after receiving training.

The results of the T-test are matched by leadership attitudes towards discipline, obtaining an average number of attitudes (mean) at the value of leadership attitude $=$ 93.5333, and the average value (mean) on the value of discipline attitude $=84.4667$. These results show that the average value (mean) of leadership attitudes obtains a higher value.

Correlation test to prove whether there is a relationship or influence between leadership attitudes to discipline attitudes obtained a significant value of 0.893 , where $0.893>0.05$ means there is no significant relationship or influence between leadership attitudes to discipline attitudes. This means that the average value of leadership attitudes higher than the value of discipline attitudes does not affect each other.

The results of the paired t-test to find out whether or not there is a difference between the value of leadership attitude to the value of discipline attitude obtained a significant value of 0.000 , where $0.000<0.05$, meaning there is a difference in the value of leadership attitude to the value of discipline attitude. The results of the analysis have shown that the value of leadership and the value of 
discipline are not derived from the same activities, but obtained from different sources of activities (Rismayadi \& Maemunah, 2016) [24].

The researchers concluded that the average increase in leadership attitudes was not the result of an increase in the pre-test to post-test scores. This condition is proven from the correlation test results and paired t-test that proves there is no relationship and no difference between pre-test and post-test. The increase is likely the result of other variables or other activities that need to be followed through further research.

Further conclusions about the increase in average value (mean) in discipline attitudes have been proven to be obtained from training results. This is evidenced by the acquisition of paired test results of t-test samples that prove significant differences in pre-test and post-test values.

The critical thing that researchers get from this study is that leadership attitudes are inversely proportional to disciplinary attitudes. Leadership attitudes in students cannot be improved through training, while discipline attitudes can be improved through training. Leadership attitudes exist first and can be referred to as carrying attitudes before students' activities in the organization (Sari et al., 2012) [18]. On the other hand, discipline is not carried out with students, but is obtained through training and other similar activities. Discipline is not an initial requirement before students enter organizational activities. Disciplinary attitudes are formed through processes, and the results are individual.

\section{Conclusions}

Leadership attitudes in students are already owned by students before and when activities in the organization. Leadership attitude is an absolute requirement that students who are active in the organization must-have. Leadership is an innate attitude and will continue to grow in line with students' activities in organizing.

Discipline attitudes are formed through training or other activities. Moreover, there was a significant increase in disciplinary attitudes after the training activities were carried out. Disciplinary attitudes are individual, meaning they are not the same as individuals. However, the process of discipline can be improved.

It concluded that there was no significant connection or influence between leadership attitudes to discipline. There is a significant difference between the value of leadership attitudes and the value of discipline attitudes. The increase in the value of leadership attitudes will not significantly affect the increase in the value of discipline attitudes. Leadership attitudes have an inverse effect on the value of discipline.

\section{Acknowledgment}

Researchers thank all parties who have helped smooth this activity, ranging from the management of research licenses to the implementation of research to run smoothly. The parties that have helped, among others, come from the school where this research has been carried out. The principal, the deputy principal, the teacher involved, as well as the students. Researchers involve students in the technical implementation of training and data collection. The head of the related institution also facilitates the preparation of correspondence for the purposes of assignment letters and research permits.

\section{REFERENCES}

[1] T u'u, T. (2004). Role of Discipline in Student Behavior and Achievement, Jakarta: PT. At Gramedia Widia Sarana Indonesia.

[2] Meitha, A., \& Sasmito, C. (2016). The influence of leadership, discipline, and communication on public services in Sambas Regency Health Center. Journal of Social and Political Sciences.

[3] Bekti Agustiningrum, MD (2018). Planting the Process of Self-Discipline of Children with Special Needs (Speech Impaired) In Traditional Dance Learning. Early Horizons: Journal of Early Childhood Education. https://doi.org/10.17 509/cd.v5i1.10493

[4] Whiteneck, G., \& Dijkers, MP (2009). Difficulty Measuring Construction: Conceptual and Methodological Problems Regarding Participation and Environmental Factors. Archives of Physical Medicine and Rehabilitation. https://doi.org/10.1016/j.apmr.2009.06.009

[5] Lickona, T. (2013). Character Education: A Complete Guide to Educating Students to Be Smart and Good. In Bandung: Nusa Media.

[6] Yudhawati, D. (2018). Implementation of Positive Psychology in Student Personality Development. Psycho Idea.

[7] Deni, M. (2018). Discipline and Motivation to the Performance of Public Service Employees. SRIWIJAYA JOURNAL OF MANAGEMENT AND BUSINESS. https://doi.org/10.29259/jmbs.v16i1.6245

[8] Handayani, DAK (2018). Improving the Satisfaction of Guidance and Counseling Services through Quality of Service, Service Requests, and Service Value. Journal of Educational Development, 6.3, 356-368.

[9] Mulyasa, E. (2013). Principal Leadership Management. PT Bumi Aksara.

[10] Muslich, M. (2008). KTSP Competency-Based and Contextual Learning. Jakarta: PT. Earth Script. 
[11] Retmono, A. W. (2016). Analysis of the Influence of Servant Leadership Style and Organizational Culture on Organizational Commitment in Improving Employee Performance (Study on Regional Development Planning Agency of South Bengkulu Regency). Master of Management, Diponegoro University.

[12] Rivai, V., Bachtiar, \& Amar, RB (2014). Leaders and Leadership in the Organization. Scientific Frum. https://doi.org/10.1016/j.eururo.2010.11.021

[13] Wartono, T. (2017). Effect of Work Stress on Employee Performance: Case Study on Mother and Baby Magazine Employees. Scientific Journal of The Management Study Program of Pamulang University.

[14] Ahmad, A., \& Salim, S. (2011). The effect of psychological intervention in reducing disciplinary cases among Malaysian secondary school students. Procedia - Social and Behavioral Sciences. https://doi.org/10.1016/j.sbspro.2011.10.507

[15] Mandey, S., \& Sahangggamu, P. (2014). THE EFFECT OF JOB TRAINING, MOTIVATION, AND DISCIPLINE ON EMPLOYEE PERFORMANCE IN PT. PEOPLE'S CREDIT BANK DANA RAYA. Journal of Economic Research, Management, Business, And Accounting. https://doi.org/10.35794/emba.v2i4.6359

[16] Susanty, A., \& Baskoro, SW (2013). The Effect of Work Motivation And Leadership Style on Work Discipline Seems to Be On Employee Performance (Case Study On PT. PLN (PERSERO) APD Semarang). J @ TI UNDIP: Journal of Industrial Engineering.https://doi.org/10.12777/jati.7.2.7784

[17] Moraes, G., Nunes, A. de S., Batista, RJ de M., Corona, LFP, \& Habitante, CA (2019). Relationship of motor performance and body composition of school teenagers. Journal of Human Growth and Development. https://doi.org/10.7322/j hgd. 157754

[18] Sari, R., Muis, M., \& Hamid, N. (2012). The Influence of Leadership, Motivation, and Work Stress on Employee Performance at Bank Syariah Mandiri Makassar Branch Office. Journal of Analysis.
[19] Syahrial, Asrial, Husni Sabil, A. (2020). No title. Universa Journal of Education Research, 8 (1) (Student Attitude, Confidence, and Self-Reliance in Thematic Learning), $162-168$

[20] Stevens, A. (2011). Telling policy stories: An Ethnographic study of the use of evidence in policy-making in the UK. Journal of Social Policy.https://doi.org/10.1017/S00472794 10000723

[21] Nasir, S., \& Rosenthal, D. (2009). The social context of initiation into injecting drugs in the slums of Makassar, Indonesia. International Journal of Drug Policy. https://doi.org/10.1016/j.drugpo.2008.02.001

[22] Gunarsa; Gunarsa, YSD (2016). Child and adolescent psychology. Journal of Information and Chemical Modeling.

[23] Möller, J., Zitzmann, S., Helm, F., Machts, N., \& Wolff, F. (2020). A Meta-Analysis of Relations Between Achievement and Self-Concept. Review of Educational Research. https://doi.org/10.3102/0034654320919354

[24] Rismayadi, B., \& Maemunah, M. (2016). The Influence of Work Motivation, Leadership, and Organizational Culture on Employee Job Satisfaction and Its Impact on Company Performance (Case study on PT. Concord, Indonesia). Journal of Management \& Creative Business. https://doi.org/10.36805/manajemen.v2i1.181

[25] Jaupllari, S., \& Olta, Zoto. (2013). An Assessment of Demand for Imports through the VECM Methodology Model. Journal of Knowledge Management, Economics, and Information Technology.

[26] Solanki, S., Fitzpatrick, D., Jones, M. R., \& Lee, H. (2020). Social-psychological interventions in college: A meta-analysis of effects on academic outcomes and heterogeneity by study context and treated population. Educational Research Review. https://doi.org/10.1016/j.edu rev.2020.100359

[27] R, K. (2011). Research Methodology. In SAGE Publication Inc. 